\title{
Factors influencing strength and setting time of fly ash based-geopolymer paste
}

\author{
Adhitya Leonard Wijaya ${ }^{1, *}$, Januarti Jaya Ekaputri ${ }^{1,2, *}$, and Triwulan ${ }^{1}$ \\ ${ }^{1}$ ITS Surabaya, Civil Engineering Department, 60111 Surabaya, Indonesia \\ ${ }^{2}$ Konsorsium Riset Geopolimer Indonesia, Concrete Building Material Laboratory, Civil Engineering \\ Department of ITS, Surabaya, 60111, Indonesia
}

\begin{abstract}
In general, fly ash is often used as a binder in geopolymer mixture. In this paper, seven samples of fly ash were collected from five Indonesian power plants. The variation of fly ash may depend upon many factors. However, there is no standardization of fly ash used for geopolymer binder. This experiment was conducted to study and categorize fly ashes both by assessing their physical and chemical characters. All fly ashes were activated with alkali activator to prepare geopolymer paste. Ratio of fly ash to the alkali activator was kept constant at $65: 35$. Compression test was conducted at three, seven, $14,21,28$, and 56 days to identify the strength development of each sample. The result revealed that the content of $\mathrm{CaO}$ in fly ash affected the setting time and early strength development. In three days paste with $\mathrm{CaO}$ content more than $20 \%$ gain $54 \%$ of its 28 -day strength. It is caused by both hydration and polymerization reactions. A range of $\mathrm{Si}$ to $\mathrm{Al}$ ratio contributed to the strength.
\end{abstract}

\section{Introduction}

Indonesia has approximately more than 85 coal-fired power plants. These power plants contribute to million tons of fly ash every year. Unfortunately, the utilization of fly ash is still far from optimal. The ashes are just pilled up on the ground without any application. An innovative effort leads to attempt to use fly ash as a sustainable eco-friendly material. Geopolymer concrete is one of the examples of green material, which uses non-Portland cement as a binder. One of the potential Portland-cement replacements is fly ash, which is activated with alkali to form binder.

The problem of application of fly ash in geopolymer concrete is the fact that every fly ash from each power plant has different characteristics. It causes a problem to control gepolymer products. There are many factors influencing fly ash properties. To utilize fly ashes from these power plants, characterization is required to assess its effects on geopolymer mixtures.

The important point to identify fly ash character in geopolymer is its setting time and strength in paste form. Setting time is the most important thing to identify because if the paste set rapidly, it is impossible to apply the paste in concrete. There are many factors that

* Corresponding author: adhityaleonard4@gmail.com and januartije@gmail.com 
relate to setting time and compressive strength of geopolymer pastes such as physical properties and chemical properties. [1-3]

Davidovits [4] stated that $\mathrm{pH}$ is one of the indicators to determine the character of fly ash. Physical properties such as fineness affected the strength of geopolymer pastes. The Finer fly ash results to higher compressive strength as found by Somna, et al. [5].

From the chemical component Subaer, et al. [6] explained that Si/Al had some impact on the compressive strength of geopolymer, compressive strength increased as the increasing of the ratio of $\mathrm{Si}$ to $\mathrm{Al}$ but at some point it would decrease. According to Antoni, et al. [7], the higher $\mathrm{CaO}$ content made the setting time of the paste become faster. Hardjito [8] explained that high content of $\mathrm{CaO}$ make geopolymer experienced both polymerization and hydration reactions that result to higher strength and accelerate the setting time of geopolymer paste.

\section{Materials}

Seven samples of fly ash from five different coal-fired power plants were being tested. The name of fly ash is arranged in alphabetical order from A to G. Fly ash A and fly ash B were collected from Paiton power plant, C and D were collected from Indramayu power plant, fly ash E from Pacitan power plant, fly ash F from Rembang power plant, and fly ash G was collected from Tanjung Awar-Awar power plant.

These fly ashes were divided into two classes based on ASTM C618 [9]. This categorization was based on the contents of $\mathrm{SiO}_{2}, \mathrm{Al}_{2} \mathrm{O}_{3}$, and $\mathrm{Fe}_{2} \mathrm{O}_{3}$ in the fly ash. If the content of $\mathrm{SiO}_{2}, \mathrm{Al}_{2} \mathrm{O}_{3}$, and $\mathrm{Fe}_{2} \mathrm{O}_{3}$ are more than $70 \%$ then it categorized as $\mathrm{F}$ class, and if the content only $50 \%$ or more then it classified as $\mathrm{C}$ class. As being shown in the Table 1 fly ash A, C, D, E, and F are categorized as F class, while fly ash B and G are classified to $\mathrm{C}$ class.

Alkali activator being used was the mixture of sodium hydroxide $(\mathrm{NaOH}) 8 \mathrm{M}$ and sodium silicate $\left(\mathrm{Na}_{2} \mathrm{SiO}_{3}\right) \mathrm{BE}-58$ that consist of $19 \%, \mathrm{H}_{2} \mathrm{O}, 36 \% \mathrm{SiO}_{2}$, and $45 \% \mathrm{Na}_{2} \mathrm{O}$. The weight ratio of $\mathrm{Na}_{2} \mathrm{SiO}_{3}$ to $\mathrm{NaOH} 8 \mathrm{M}$ that being used was two.

Table 1. Chemical composition of fly ashes (\% weight)

\begin{tabular}{|c|c|c|c|c|c|c|c|c|}
\hline NO & OXIDES & $\mathrm{A}$ & $\mathrm{B}$ & $\mathrm{C}$ & $\mathrm{D}$ & $\mathrm{E}$ & $\mathrm{F}$ & $\mathrm{G}$ \\
\hline 1 & $\mathrm{SiO}_{2}$ & 45.82 & 32.49 & 41.22 & 46.67 & 46.41 & 37.94 & 27.04 \\
\hline 2 & $\mathrm{Al}_{2} \mathrm{O}_{3}$ & 24.09 & 13.43 & 18.71 & 24.92 & 26.58 & 22.67 & 18.18 \\
\hline 3 & $\mathrm{Fe}_{2} \mathrm{O}_{3}$ & 11.57 & 23.59 & 16.21 & 11.59 & 9.80 & 16.53 & 17.73 \\
\hline 4 & $\mathrm{TiO}_{2}$ & 1.05 & 0.78 & 0.71 & 0.76 & 0.79 & 0.77 & 0.66 \\
\hline 5 & $\mathrm{CaO}$ & 8.03 & 14.83 & 12.20 & 7.07 & 8.23 & 11.76 & 21.08 \\
\hline 6 & $\mathrm{MgO}$ & 3.56 & 10.71 & 6.03 & 4.58 & 3.88 & 5.78 & 8.69 \\
\hline 7 & $\mathrm{~K}_{2} \mathrm{O}$ & 1.66 & 0.87 & 0.89 & 0.69 & 0.66 & 0.94 & 1.04 \\
\hline 8 & $\mathrm{Na}_{2} \mathrm{O}$ & 1.20 & 0.65 & 1.01 & 0.97 & 1.51 & 1.25 & 1.96 \\
\hline 9 & $\mathrm{SO}_{2}$ & 0.56 & 1.03 & 1.40 & 0.68 & 0.63 & 0.74 & 2.40 \\
\hline 10 & $\mathrm{Mn}_{2} \mathrm{O}_{3}$ & 0.11 & 0.44 & 0.31 & 0.21 & 0.17 & 0.25 & 0.36 \\
\hline \multicolumn{2}{|c|}{$\mathrm{SiO}_{2}+\mathrm{Al}_{2} \mathrm{O}_{3}+\mathrm{Fe} 2 \mathrm{O}_{3}$} & 81.48 & 69.51 & 76.14 & 83.18 & 82.79 & 77.14 & 62.95 \\
\hline \multicolumn{2}{|c|}{ Classification } & $\mathrm{F}$ & $\mathrm{C}$ & $\mathrm{F}$ & $\mathrm{F}$ & $\mathrm{F}$ & $\mathrm{F}$ & $\mathrm{C}$ \\
\hline
\end{tabular}




\section{Methods}

The weight proportion of geopolymer paste mixture used was $65 \%$ fly ash and $35 \%$ alkali activator. Ratio $\mathrm{Na}_{2} \mathrm{SiO}_{3}$ to $\mathrm{NaOH} 8 \mathrm{M}$ by mass was two. This composition was blended to react with fly ash.

Procedure to make the geopolymer paste was by blending the composition using a mixer then put it in the cylinder mold that already prepared. The mold has dimension of 2 $\mathrm{cm}$ in diameter and $4 \mathrm{~cm}$ in height. All the specimens of paste were kept at moist curing in room temperature until the day of test.

Some series of analysis were conducted for fineness, specific gravity, $\mathrm{pH}$ test, and $\mathrm{X}$ Ray Fluorescence (XRF) test. Fineness test of fly ash was performed using a sieve no. 325 (45 $\mu \mathrm{m})$ based on ASTM C430-96 [10]. The test results were analyzed for each setting time and compressive strength of pastes. Setting time test followed the procedure from ASTM C191 [11]. Setting time is the most important factor to be investigated from the fly ashpaste. This test objective was to understand the time to make the mixture and also determine the suitability of fly ash when being used in geopolymer concrete mixtures. Setting time test was conducted using vicat to calculate the initial and final setting of each fly ash. Initial setting time was calculated as the time elapsed between the initial contact of fly ash and alkali activator and when the penetration was at $25 \mathrm{~mm}$ from the surface. Final setting occurred when the penetration of vicat was zero $\mathrm{mm}$. Compressive strength test followed the procedure from ASTM C109 [12]. The compressive strength was tested at three, seven, 14, 21, 28 and 56 days. The strengths were calculated from the average of six identical specimens.

\section{Results and Analysis}

Setting time of pastes is listed at Table 2. Setting times of paste were greatly influenced by $\mathrm{CaO}$ content in the fly ash. Table 2 illustrates fly ash $\mathrm{A}, \mathrm{D}$, and $\mathrm{E}$ had very long setting time it occurs because $\mathrm{CaO}$ content in fly ash $\mathrm{A}, \mathrm{D}$, and $\mathrm{E}$ was below $10 \%$. Fly ash $\mathrm{C}$ and $\mathrm{F}$ had a similar setting time to Portland-cement paste. It is shown that $\mathrm{CaO}$ content of fly ash $\mathrm{C}$ and $\mathrm{F}$ is quite high, which is above $10 \%$. Fly ash $\mathrm{G}$ set rapidly in 18 minutes. It was affected by its $\mathrm{CaO}$ content is more than $20 \%$. It causes fly ash $\mathrm{G}$ become impossible to use in the concrete mixture. Figure 1 shows the higher $\mathrm{CaO}$ content then setting time of the paste will get faster. It shows that setting time will decrease exponentially as the increase of $\mathrm{CaO}$ content. From the Figure 1, it is possible to predict the setting time of geopolymer paste using formula :

$$
S T=4838,7 \cdot \mathrm{e}^{-0.262 \mathrm{CaO}}
$$

ST : setting time (minutes)

e : exponential number $(2,72)$

$\mathrm{CaO}: \mathrm{CaO}$ content ( $\%$ fly ash mass)

Diaz, et al. [13] stated that fly ash was suitable as a concrete mixture when the $\mathrm{CaO}$ content is between $5 \%$ until $15 \%$. Based on data of setting time, fly ashes that applicable for geopolymer mixture are fly ash A and E. Setting time of paste made from fly ash A and $\mathrm{E}$ are quite long at about nine hours. In the field, setting time of geopolymer concrete almost half of the geopolymer paste's setting time, for that reason fly ash A and E are the proper choices as the binder of geopolymer. 
Table 2. Initial and final setting time of fly ash

\begin{tabular}{cccccccc}
\hline Code & A & B & C & D & E & F & G \\
\hline Initial Setting Time (minutes) & 378 & 72 & 120 & 590 & 377 & 85 & 10 \\
Final Setting Time (minutes) & 585 & 129 & 225 & 827 & 530 & 160 & 18 \\
\hline
\end{tabular}

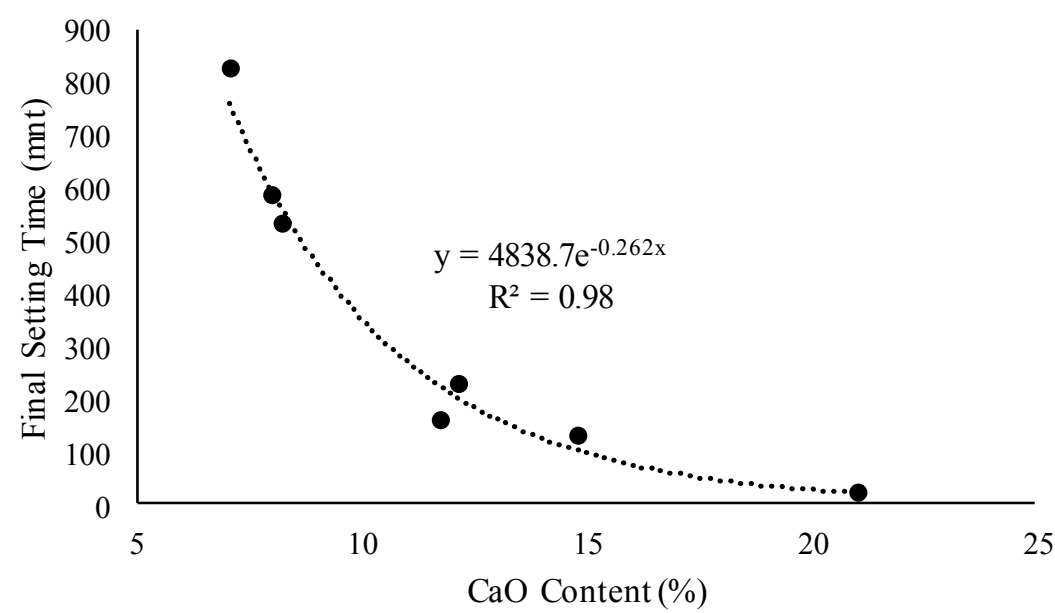

Fig. 1. Relation between $\mathrm{CaO}$ content and final setting time

Figure 2 shows the strength of pastes at different days, Nurwidayati, et al. [14] stated that the increase of the age result in higher strength of the paste. The strength of geopolymer paste still kept increasing even after 28 days. Fly ash D gained the highest strength at 28 days $50.30 \mathrm{MPa}$, while compressive strength of fly ash B is the lowest of all with $32.84 \mathrm{MPa}$. It shows that even at 28-day fly ash $\mathrm{D}$ gain the best strength, but at three days it compressive strength was only $12.26 \mathrm{MPa}$, while the highest strength at three days was fly ash G with $21.08 \mathrm{MPa}$. Based on the result of setting time and strength, fly ash A and $\mathrm{E}$ are the most applicable fly ash for geopolymer mixtures. Fly ash A and E have high strength and quite long setting time, it is possible to apply them in the field.

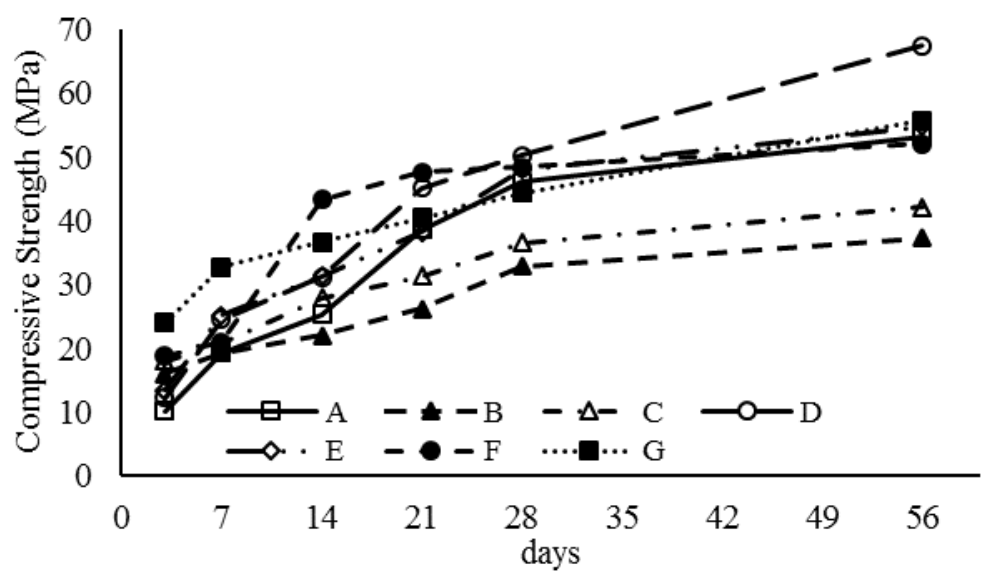

Fig. 2. Strength of geopolymer pastes at different days 
$\mathrm{CaO}$ content in fly ash besides affecting setting time also involved in early strength build-up and $\mathrm{pH}$ of fly ash. Table 3 shows $\mathrm{pH}$, strength of pastes at three days, and its percentage of 28 days strength. Higher $\mathrm{CaO}$ content will result in higher $\mathrm{pH}$ as stated by Antoni, et al. [15], but it only occurred if fly ashes with high $\mathrm{CaO}$ content $(>10 \%)$ are separated from fly ashes with low $\mathrm{CaO}(<10 \%)$ as it is shown by Figure 3. Figure 3 shows linear relation between $\mathrm{CaO}$ content and $\mathrm{pH}$ of fly ashes with $\mathrm{CaO}$ content less than $10 \%$, while for fly ashes with $\mathrm{CaO}$ content more than $10 \%$ the trend is almost linear.

Table 3. $\mathrm{pH}$, and three days strength of pastes

\begin{tabular}{cccccccc}
\hline Code & A & B & C & D & E & F & G \\
\hline $\mathrm{pH}$ & 11.9 & 11.5 & 11.6 & 11.4 & 12 & 11.6 & 12.1 \\
Three Days Strength (MPa) & 10.17 & 16.08 & 18.06 & 12.26 & 13.40 & 18.76 & 24.04 \\
Comparison with 28 days Strength (\%) & $22 \%$ & $49 \%$ & $49 \%$ & $24 \%$ & $28 \%$ & $39 \%$ & $54 \%$ \\
\hline
\end{tabular}

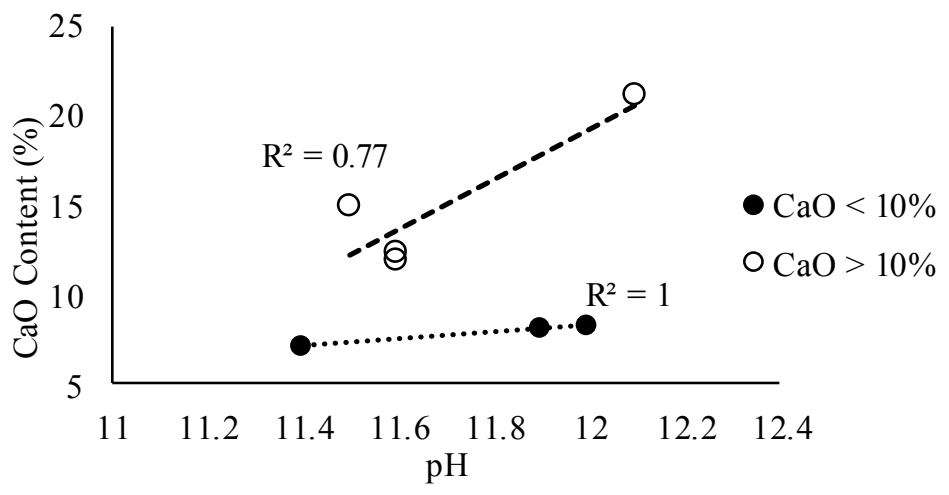

Fig. 3. Relation between $\mathrm{pH}$ of fly ash and $\mathrm{CaO}$ content

Figure 4 and Figure 5 show the effect of $\mathrm{CaO}$ content in early strength of geopolymer pastes. Figure 4 shows the relation of $\mathrm{CaO}$ and strength in $\mathrm{MPa}$ while Figure 5 shows the relation of $\mathrm{CaO}$ and strength in percentage. Both Figure 4 and Figure 5 show that $\mathrm{CaO}$ content contributes in early strength development. High $\mathrm{CaO}$ content result on a high strength, it as being stated by Antoni, et Al [16]. Risdanareni, et al. [17] explained high $\mathrm{CaO}$ content contributed higher strength. It is because of double reaction occurred within the system which are polymerization and hydration reactions. In Figure 4, highest strength occurred at fly ash with highest content $\mathrm{CaO}$. Fly ash $\mathrm{G}$ had $\mathrm{CaO}$ content of $21.08 \%$, and its strength was $24.04 \mathrm{MPa}$ while fly ash D with the lowest $\mathrm{CaO}$ content only had 12.26 MPa. Figure 5 fly ash $\mathrm{G}$ with $\mathrm{CaO}$ content $21.08 \%$ result on $54 \%$ of its 28 -day strength only in 3 days. 


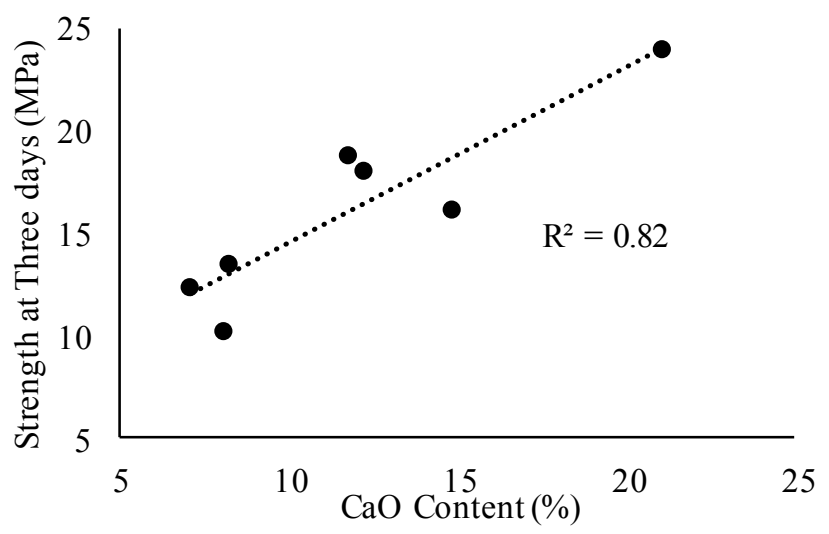

Fig. 4. Effects of $\mathrm{CaO}$ content on compressive strength at three days

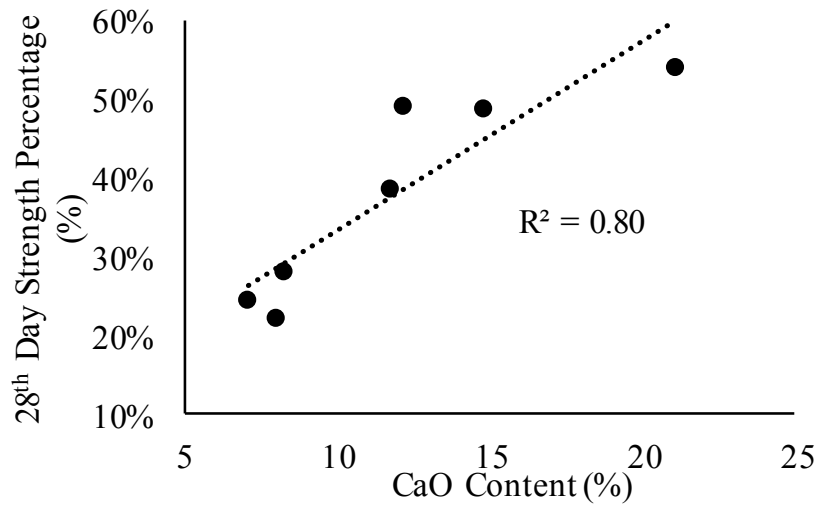

Fig. 5. Effects of $\mathrm{CaO}$ content on $28^{\text {th }}$ day strength percentage

Strength of geopolymer paste at 28-day was affected by both physical and chemical properties of fly ash as shown in Table 4 . Physical property that dominantly affected the strength is fineness, while chemical property that contributes significantly is ratio Si to Al. The numbers in fineness parameter were indicated percent material retained in the sieve no. 325 .

Table 4. Physical and Chemical Properties Affect Geopolymer Pastes Strength

\begin{tabular}{cccccccc}
\hline Code & A & B & C & D & E & F & G \\
\hline Fineness (\% retained) & 30 & 41 & 31 & 27 & 30 & 29 & 27 \\
Si/Al & 2.078 & 2.883 & 2.466 & 2.038 & 1.902 & 1.912 & 1.875 \\
Comp. Strength at 28 days (MPa) & 46.06 & 32.84 & 36.59 & 50.30 & 48.01 & 48.45 & 44.39 \\
\hline
\end{tabular}

Figure 6 illustrates that fineness has a significant impact on increasing paste strength. It was as being explained by Soutsos, et al. [18] fineness of fly ash contributes more to the strength of geopolymer compared to the other physical properties. 


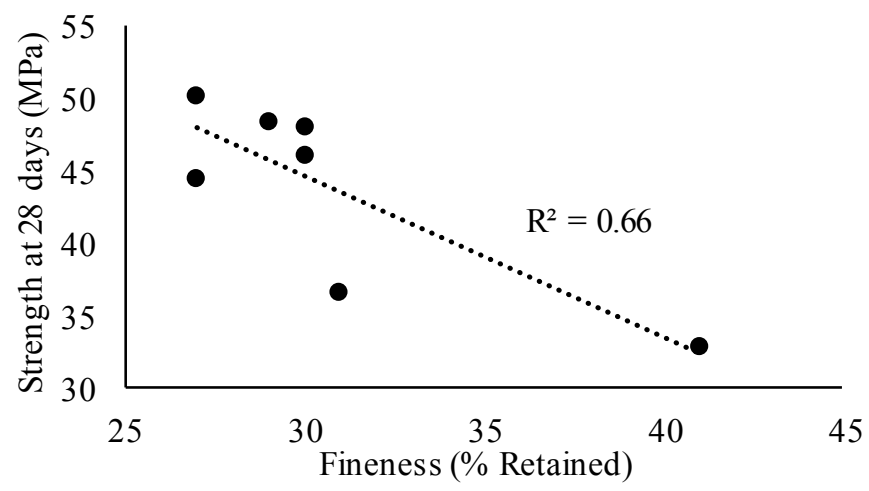

Fig. 6. Relation between Fineness and Compressive Strength at 28 Days

Chemical property contributes to the strength of geopolymer pastes was the ratio of $\mathrm{Si} / \mathrm{Al}$. From Figure 7 shows that pastes have high strength when ratios of Si to Al were around two. While the ratios of $\mathrm{Si} / \mathrm{Al}$ are at the range of 1.875 to 2.078 the compressive strengths are between $44.39 \mathrm{MPa}$ and $50.30 \mathrm{MPa}$. The strength then keeps decrease as the increase of Si to Al ratio. Asif, et al. [19] explained that the increasing of ratio Si/Al produce higher strength. The optimum strength of geopolymer was occurred when the ratio of $\mathrm{Si}$ to $\mathrm{Al}$ is equal to two, when the ratio of $\mathrm{Si}$ to $\mathrm{Al}$ more than two then the strength kept decrease. Asif, et al. conducted the research using various specimens with the ratio of Si to $\mathrm{Al}$ from 1.85 to three. Zhou, et al. [20] also stated the optimal condition of fly ash basedgeopolymer occurred when the ratio of $\mathrm{Si}$ to $\mathrm{Al}$ equals to two. Chemical composition has greater effect upon the strength of paste than the physical property of fly ash. Ratio Si to Al contributes more to the strength compares to fineness of fly ash.

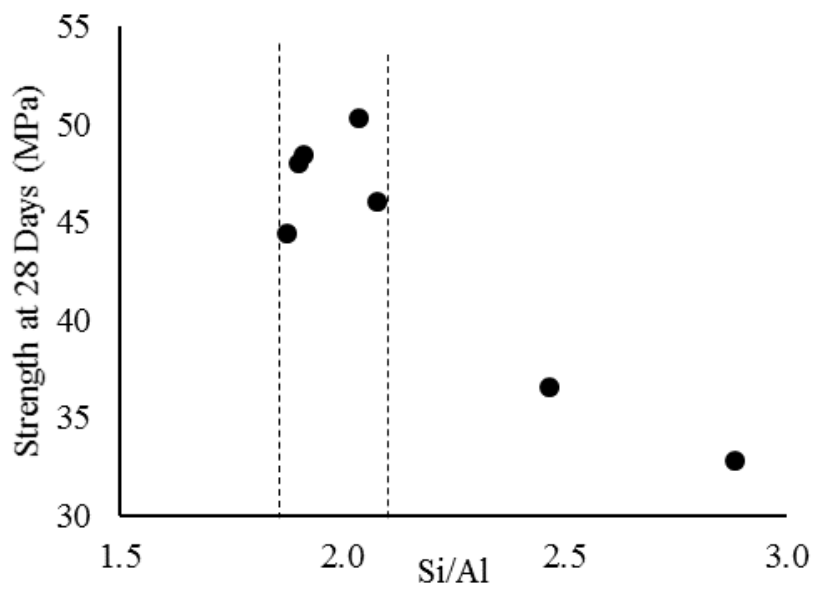

Fig. 7. Relation between $\mathrm{Si} / \mathrm{Al}$ and Strength at 28 Days 


\section{Conclusions}

1. $\mathrm{CaO}$ content of fly ash contributes to faster setting time of geopolymer paste due to double reaction of geopolymerization and hydration process. This double reaction also increased the early strength of geopolymer pastes, especially at three days. Fly ash $\mathrm{G}$ with $\mathrm{CaO}$ content more than $20 \%$ obtained $54 \%$ of its 28 -day strength.

2. $\mathrm{pH}$ of fly ash severely was influenced by $\mathrm{CaO}$ content. The $\mathrm{pH}$ increased as $\mathrm{CaO}$ content increased. However, there should be separation between fly ash with $\mathrm{CaO}$ content more than $10 \%$ and less than $10 \%$ by fly ash mass.

3. Fineness contributes to compressive strength of geopolymer pastes. Finer fly ashes resulted in higher compressive strength.

4. The ratio of $\mathrm{Si}$ to Al influences to the strength of geopolymer pastes. Compressive strengths are optimal when the ratios of $\mathrm{Si}$ to $\mathrm{Al}$ are around two. When this ratio was between 1.875 and 2.078 then the strengths at 28 days were in the range of $44.39 \mathrm{MPa}$ to $50.30 \mathrm{MPa}$.

5. Chemical composition contributes more to the strength and setting time of paste compares to physical properties of fly ash.

6. Based on setting time and strength, fly ash A and E are the most applicable materials for geopolymer concrete.

\section{References}

1. X. Gao, Q. L. Yu, H. J. H Brouwers, Construction and Building Materials, 98, p. 397406 (2015)

2. S. Alehyen, M. El Achouri, M. Taibi, "Journal of Materials and Environmental Sciences", 8, issue 5, 1783-1796 (2017)

3. X. Y. Zhuang, L. Chen, S. Komarneni, C. H. Zhou, D. S. Tong, H. M. Yang, W. H. Yu, H. Wang, "Journal of Cleaner Production", 125, 253-267 (2016)

4. J. Davidovits, "Geopolymer chemistry and applications 2nd ed. Saint-Quentin (France: Institute Géopolymère)", (2008)

5. K. Somna, C. Jaturapitakkul, P. Kajitvichyanukul, P. Chindaprasirt, FUEL, 90, 2118 $2124(2011)$

6. Subaer, A. Haris, Nurhayati, A. Irhamsyah, J. J. Ekaputri, "Materials Science Forum", 841, 170-17 (2016)

7. Antoni, S, W. Wijaya, D. Hardjito, "Material Science Forum”, 841, $90-97$ (2016)

8. D. Hardjito, "Studies on fly ash-based geopolymer concrete (Curtin University of Technology. Perth, Australia)", 2005

9. American Society for Testing and Materials, ASTM C618 (2004)

10. American Society for Testing and Materials, ASTM C430 - 96 (1996)

11. American Society for Testing and Materials, ASTM C191-13 (2013)

12. American Society for Testing and Materials, ASTM C109 / C109M-02 (2002)

13. E. I. Diaz, E. N. Allouche, S. Eklund, FUEL, 89, 992-996 (2010)

14. R. Nurwidayati, M. B. Ulum, J. J. Ekaputri, Triwulan, P. Suprobo, "Material Science Forum", 841, 118-125 (2016)

15. Antoni, R. Gunawan, D. Hardjito, “Applied Mechanics and Materials”, 815, 153-157 (2015)

16. Antoni, S, W. Wijaya, D. Hardjito, “Material Science Forum”, 841, 98-103 (2016) 
17. P. Risdanareni, P. Puspitasari, J. J. Ekaputri, "MATEC Web of Conferences", 97, (2017)

18. M. Soutsos, A. P. Boyle, R. Vinai, A. Hadjierakleous, S. J. Barnett, "Construction and Building Materials", 110, 355-368 (2016)

19. A. Asif, Z. Man, M. Azizli, K. Azizi, M.F. Nuruddin, L. Ismail, "Material Science Forum", 803, 355 (2014)

20. W. Zhou, C. Yan, P. Duan, Y. Liu, Z. Zhang, X. Qui, D. Li, Materials \& Design, 95, p. 63-74 (2016) 